\title{
外海に面した中規模海水浴場の波と流れに関する調査事例
}

\section{A Field Survey of Waves and Currents in Seabathing Area facing Open Sea}

\author{
高橋重雄 ${ }^{*}$ 鈴木高二朗* 岡村知光 ${ }^{* *}$ 三浦裕信 ${ }^{* * *}$ \\ 坂本峻二**** 小林雅彦 ${ }^{* * * * *}$
}

Shigeo Takahashi, Kojiro Suzuki, Tomomitsil Okamura, Hironobu Miura

Syunji Sakamoto, Masahiko Kobayashi

\begin{abstract}
Seabathing is a very popular sea activity in Japan. However many people were involved in accidents during bathing, and unfortunately, over one hundred people were killed each year. A series of studies are being conducted to investigate the causes of accidents and to improve the safety of the activity. In this report,waves and currents, and movements of bathing people driven by them are measured in a coast of a small island in the Pacific Ocean.
\end{abstract}

Keywords: seabathing, sea accidents, people's safety

1.まえがき

海水浴は身近な夏のレジャーであり年間 1 億人の,々々が楽しんでいる。ただし調査によると海水浴では多くの 人々が事故に遭っており、例えば平成 6 年では 207 人の方の死亡が報告されている。したがって市民の安全性 を確保する技術の確立が必要となっており、土木工学の観点 (安全な海浜を創る技術等) からも検討すべきこと は少なくない。しかしながら、そうした研究は少なく現地のデータも少ない（堀川ら (1972)、佐々木ら (1974)、 井上ら (1988)、小舟 (1990)、宇多ら (1991))。

筆者らは海水浴における安全性を高めるための基礎的なデータを得ることを目的として平成 5 年度から夏期に 海水浴の安全性に関する現地調査を行っている。平成 5 年度には、首都圈中心の 11 の海岸のライフガードのレ スキューレポートをもとにして、海水浴での事故の全体像をつかむための基礎的なデータ（事故と対策の現状） をとりまとめている。その結果、海水浴場によっては事故が多発している海岸とそうでない海岸があることや、 事故原因が流れ、風、波という気象海象条件によるものが多いというようなことが分かっている。また、平成 6 年度は伊豆の一海岸を対象にさらに詳しい調査を行っている（塩見ら (1995)）。しかし、この時の調査では波、 流れ、風等を定量的に調査しておらず、気象海象条件がどのように事故と結びつくのかという事故発生メカニズ ムについてはあまり知見が得られていない。そこで平成 7 年度は特徵の異なる 4 つの海岸で波・流れ・風と事故 との関係をできるだけ定量的に把握することを目的として調査を行っている (金澤ら(1996))。

平成 8 年度にはその結果をもとに気象海象条件が比䩙的厳しい離島のM海岸を対象にさらに詳しい調査を行っ ている。本報告はこの平成 8 年度の調查に基づく ものである。

\section{2. 調查内容}

調查は平成 8 年 7 月 30 日〜 25 日の間、特に 7 । $30 \sim 8 / 9$ を重点期間として離島の $M$ 海岸を対象に 実施した。M海岸は図ー 1 に示すように長さ約 70 Omで汀線付近がやや急勾配な砂浜海岸である。 海岸は西側に面しており南側は岩場で北側には突 堤（岸壁を兼ねた防波堤）が延びている。また沖 合約 $250 m$ 付近に潜堤が 2 基設置されている。遊 泳区域は遊泳者が潜堤や沖の方へ流されないよう にブイで囲まれている。浜の中央には監視タワー が設置され、ライフセーバーにより監視活動及び 事故発生時の救助活動が行われている。

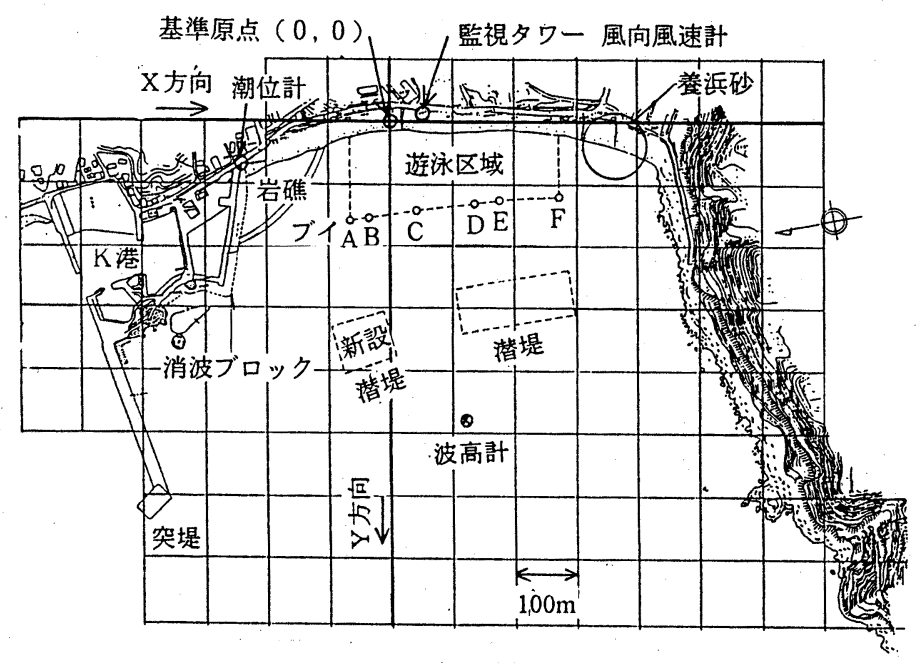

図-1 M海岸の様子

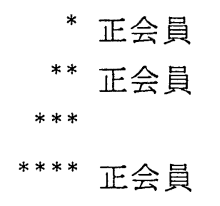

運輸省港湾技術研究所水工部耐波研究室 運輸省第四港湾建設局博多港工事事務所 運輸省第一港湾建設局秋田港工.事事務所 マリーナビーチ協会

$$
\text { ***** ライフセービング協会 }
$$


調査は主に以下の二項目である。

(1) 日常調查…調查期間中毎日所定の時刻 に各浜における気象・海象等を記録する。 なお、波高計は 2 基の潜堤の中間に、風速 計はライフセーバーの監視塔上部に設置し てある。また、潮位データは第三管区海上 保安本部より頂いている。

(2)人流れ調査…人俘かんでいる状態で 海面上にいるとき風・潮流の影響をどのよ うに受けるかを調査する。今回の調査の特 徵はこの遊泳調査において実際に人を浮か ベ、その人が波や流れにより移動するのを 測量によって追跡したことである。また、 危険な個所を対象に高さ $1 \mathrm{~m}$ の円筒状の浮 体を人の代わりに流寸ことも行っている。

\section{3 , 調查結果}

(1) M海岸の海底地形と潮位について

図一 2 は、平成 8 年 7 月 31 日に実施し た測量結果であり、干潮時（ほぼL.W.L.） に人がたてる範囲で測定したものである。 図には H.H.W.L. $(2.02 \mathrm{~m})$ と L.W.L. $(0.49 \mathrm{~m})$ と D.L.(Om) が示してある。前浜の勾配が 1 15 から 1/6 と急であり、一度少し梁くなっ て (トラフ) また浅くなっており（バ 一）、沖側に歩いていける距離が $50 \mathrm{~m}$ か ら $100 \mathrm{~m}$ である。このように低潮位では足 の着く範囲が広くて安全性が高い。ただ し、潮位が平均潮位程度 $(1.5 \mathrm{~m})$ となると 足が着く範囲が勾配の急な前浜の部分だけ となって危険である。特に波がこの付近で 砕波するため危険性が高くなる。

太平洋側では $1 \mathrm{~m}$ 以上の潮位差があり、 朝、足の着く場所が沖合遠くまで続いてい ても、夕方になると汀線付近しか足が着か ないというように、潮位によって遊泳者が 受ける海浜のイメージが大きく異なる海岸 が他にも多いものと考えられる。

\section{(2) 調查期間中の気象海象条件}

波浪の観測は 8/3〜 22 まで実施して いる。8/13 からは台風 12 号の影響で 波高が大きくなり 15 日には $4 \mathrm{~m}$ を越 え、16日まで高かった。それ以外の 日は $1 \mathrm{~m}$ 以下であった。風も計器で計 測しており、たとえば 8 月 5 日午後に はSES から SWの風が $4 \sim 6 \mathrm{~m} / \mathrm{s}$ で吹 いていた。 8 月の遊泳注意は 1 日と 16 日で、遊泳禁止は16日だけであっ た。人流れ調查を行った $7 / 30 〜 8 / 10$ にかけては比較的静稳であり、この期 間の事故は後に述べる 1 例だけであっ た。

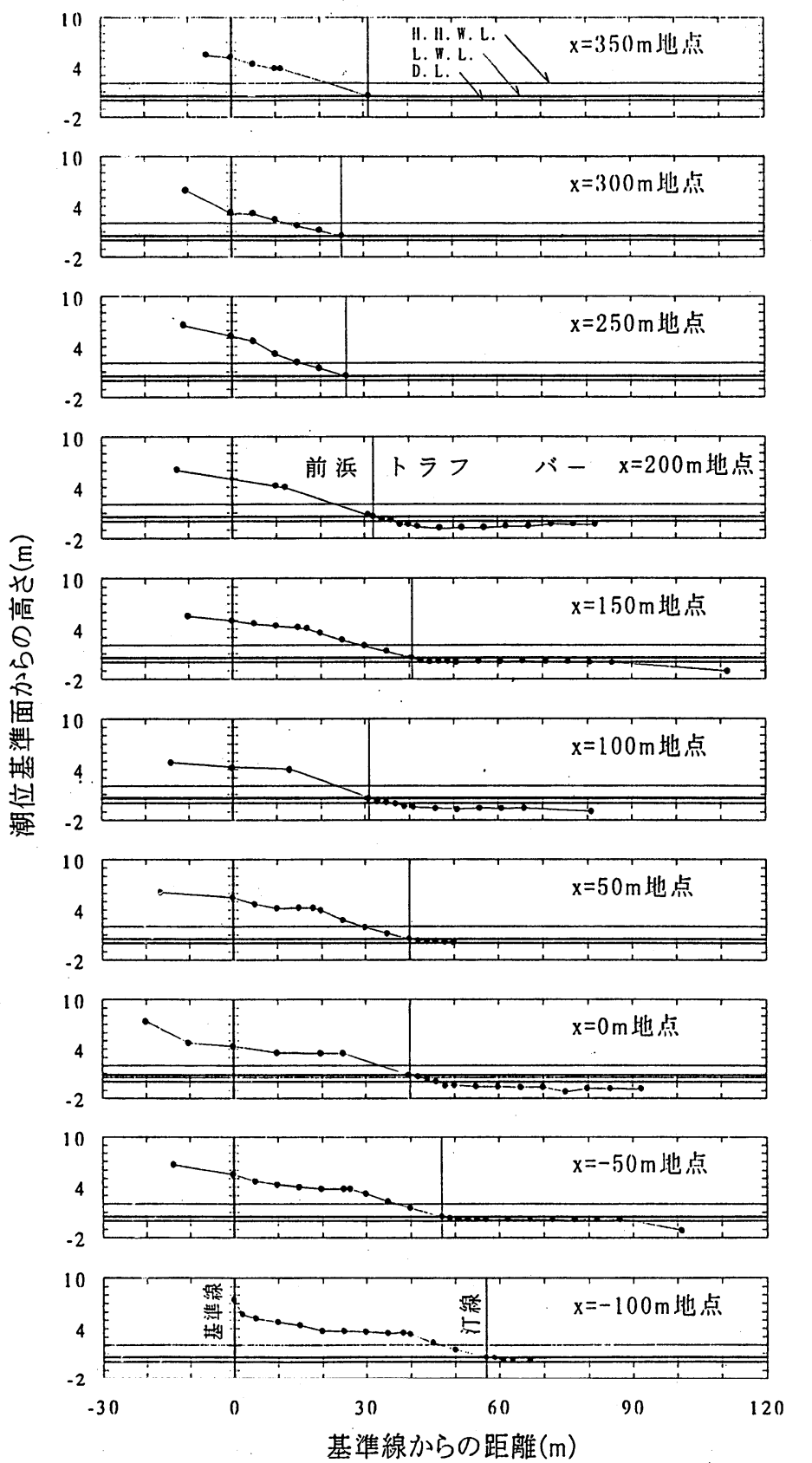

図-2 神津島前浜海岸の海底地形

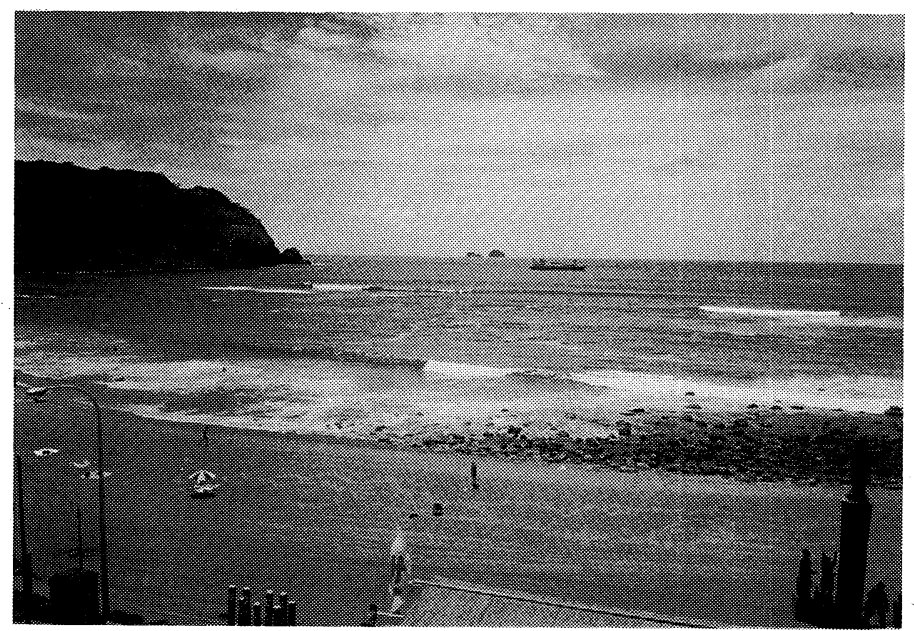

与真— 1 M海岸での砕波の状況 
(3)人流れ調査結果

(1)波による影響

8 月 1 日は波高がやや大き く遊泳注意がでていた。波高 計がまだ設置されていないた め目視による砕波波高が 1.5 $\mathrm{m}$ で風は SW、 $2 \mathrm{~m} / \mathrm{s}$ であっ た。調査時は特に潮位が低 <、D.L. $+60 \sim 100 \mathrm{~cm}$ (L.W.L. +10 50cm) であり、写真 1 のように沖の潜堤上でも砕 波している。図ー 3 はこのと きの調查結果で、砕波点のや や沖のブイ付近ではかなり速 い流れがあり、 $0.3 \mathrm{~m} / \mathrm{s}$ を越 えている。ここには示してい ないが、その後砕波帯に入る と砕波に乗るような形でさら に加速されて汀線付近に近づ いているが、潮位が低いため に足が着き、それ以上流され ることはなかった。このよう に波が高い場合には波による と思われる流れが発生する。 通常M海岸ではこの図のよう に北向きと南向きの流れに分 かれ、海岸の両端に近づくと 沖側に流されるようである。

図 -4 は参考のため平成 7 . 年 8 月 7 日に行った調查結果 を示すものであり、この日も $\mathrm{H}_{1 / 3}=0.7 \mathrm{~m}, \mathrm{~T}_{1 / 3}=5.5 \mathrm{~s}$ と遊 泳可の条件ではあったが比較 的波が大きかった。流れは汀 線付近から沖合に向からほど 速く、遊泳区域外の潜堤付近 では突堤に向かって $0.2 \mathrm{~m} / \mathrm{s}$ もの速度で流されている。特に浜の北側では突堤に向かう強い流れがあり、(1)点で の計測後、被験者であるライフセーバーがかなり沖合に流され自力で戻れず、ボートによって救助されている。

人流れ調査に引き続いてライフセーバーによる遊泳調査を行い、当海岸の安全性を評価した。安全性の評価に は A : 安全、 $\mathrm{B}$ ：やや注意、 $\mathrm{C}$ : 注意、 $\mathrm{D}$ : 遊泳禁止の直前、 $\mathrm{E}$ : 遊泳禁止（危険）、 $\mathrm{F}$ : 非常に危険という安 全度を用いている。潜堤付近や潜堤上では「注意」を表すランクCが示されている。これは潜堤の上では周辺の 区域と比較して波高が大きく流れも速いため、遊泳者が恐怖感を感じるためと思われる。また、北側に注岩礁が ありここに入り込むと危険でありランク C となっている。特に北向きの流れがある場合には、気づかないうちに この付近に流され危険であり、そこから沖に行くと突堤に向から流れがあり非常に危険となる。なお、浜の中央 部では波高の大きい日には斜めに離岸流が発生するため「やや注意」のランクBが示されている。

(2)流れに及ぼす地形と構造物の影響について

一般に言われるように海岸の流れで問題となるのはやはり離岸流であり危険性が高い。今回のM海岸は比較的 海岸の規模が小さく、離岸流は両端の岩礁付近から発生し、突堤に沿って流れるというように位置がある程度決 まっているようである。海水浴場の危険性について議論するときには、まずその大きさに注目する必要があり、 当然のことながら何キロにもおよぶ長い浜と小さい入江のような浜では大きく異なり、離岸流の発生の様子など も異なっているものと考えられる。今回対象とした海岸は中・小規模な海岸で、大規模な海岸より波や風の影響 を把握しやすい。 
また、図一 $3 、 4$ に見られる流れが潜 堤によるものかどうかはこれまでの調査 では明確ではない。また、ライフセーバ 一からのヒヤリング調査では、潜堤がで きたことによって、波高が大きい時、来 襲する波の波向きが複雑になり、予期し ない波に巻き込まれたりする危険がある とのことであった。すなわち、潜堤によ

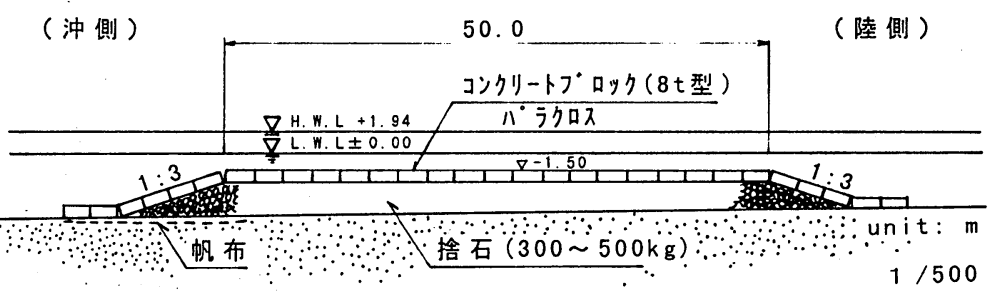
って波が回折し、海岸で複雑に砕波する ことが危険性を高めている。

図-5 M海岸の潜堤の断面図

一般に、潜堤については、それによって海水浴場内で波高が減衰していることが期待されるが、M海岸の潜堤 の天端は図－5に示すようにD.L.-1.5m（L.W.L.-2.0m）であり、平均潮位 (D.L. $+1.5 \mathrm{~m})$ 以上であれば、遊泳禁止 となるような $1.5 \mathrm{~m} \sim 2 \mathrm{~m}$ 程度の有義波高の波では、潜堤によって砕波する波は比較的少ない。したがって、満 潮時などでは潜堤によって遊泳時の波高が低減する効果はあまり期待できない。

(3)風による影響

図一 6 は 8 月 4 日の人流れ

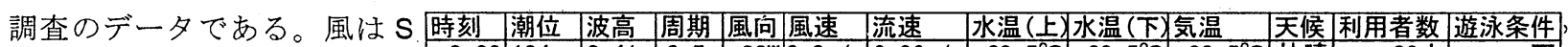
$W \sim S S W$ で平均風速 $3.5 \mathrm{~m} / \mathrm{s}$ 程度であり、波高が約 $0.5 \mathrm{~m}$ の場合である。風は必ずしも 一様ではなくある程度のばら つきがあるが被験者は 0.06 。 $0.14 \mathrm{~m} / \mathrm{s}$ の速さで沖側に運ば れている。また、浮き具をつ けた場合は 2 倍以上の速さで 進んでいる。M海岸ではこの ような南系の風で突堤（防波 堤十岸壁）の方に流され、岩 礁内に入ったり沖へ流される 危険性がある。図－7は波高 が $0.2 \sim 0.3 \mathrm{~m}$ と小さく風が $\mathrm{N}$ $\mathrm{E}$ で $3 \mathrm{~m} / \mathrm{s}$ とやや強い場合の

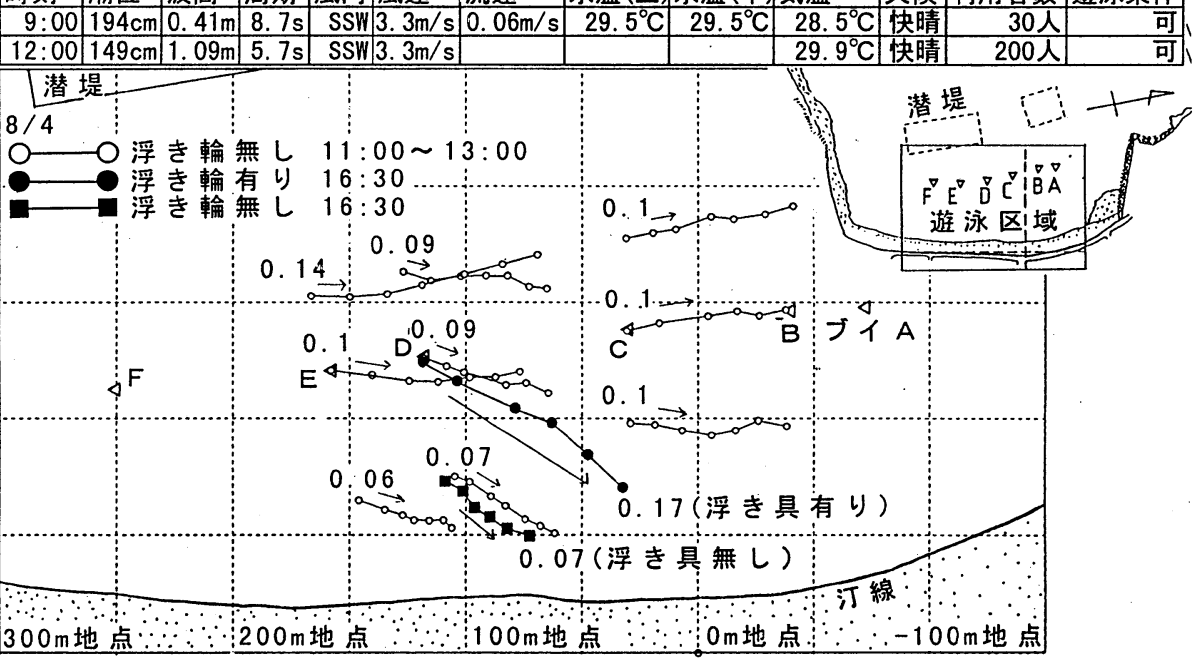

図-6人流れ調查結果（平成 8 年 8 月 4 日） データ（8月6月）である。 被験者は沖向きに $0.06 \sim 0.1$ $\mathrm{m} / \mathrm{s}$ の速さで運ばれている。

このように風によって流さ れることは少なくない。波が 小さく、人の流れに影響して いない幾つかのデータから見 ると、人の流される速さは平 均風速の約 $3 \%$ 程度のようで ある。風速は $2 \mathrm{~m} / \mathrm{s}$ 以下であ ればあまり問題ないが、 $3 \mathrm{~m} /$ $\mathrm{s}$ 以上だとその向きによって は問題となり、 $5 \mathrm{~m} / \mathrm{s}$ を越え ると遊泳注意となる場合があ る。単純に $3 \%$ とすると平均 風速 $5 \mathrm{~m} / \mathrm{s}$ で人の流れは 0.15 $\mathrm{m} / \mathrm{s}$ となり、特に沖に向かう

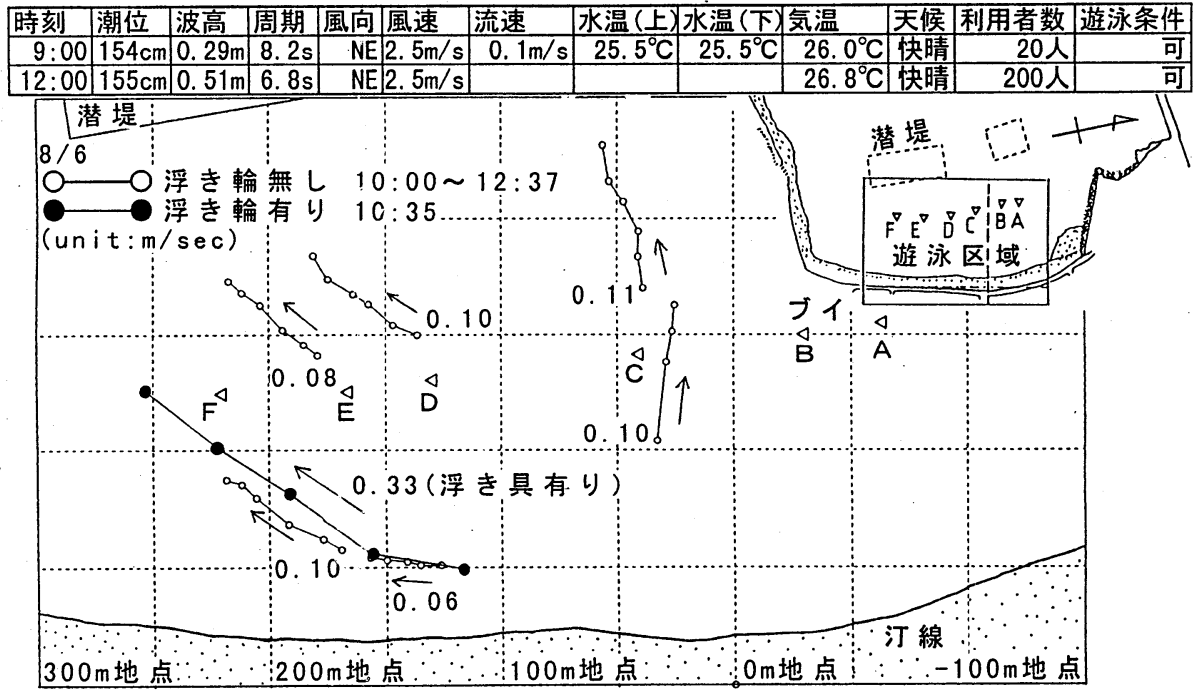

図 -7 人流れ調査結果 (平成 8 年 8 月 6 日)

風では岸に戻ってこれない可能性がある。また、風が強い時に浮き具をつけていると、風の直接的な作用（力） も加わり、流れる速さは 2 倍以上となって危険であな。特に浮き具に人が乗った状態ではさらに速くなり、付け ない場合の 3 倍にもなり危険性が増す。また、浮き輪は大きいほど風の力を受けて動きやすい傾向にある。 


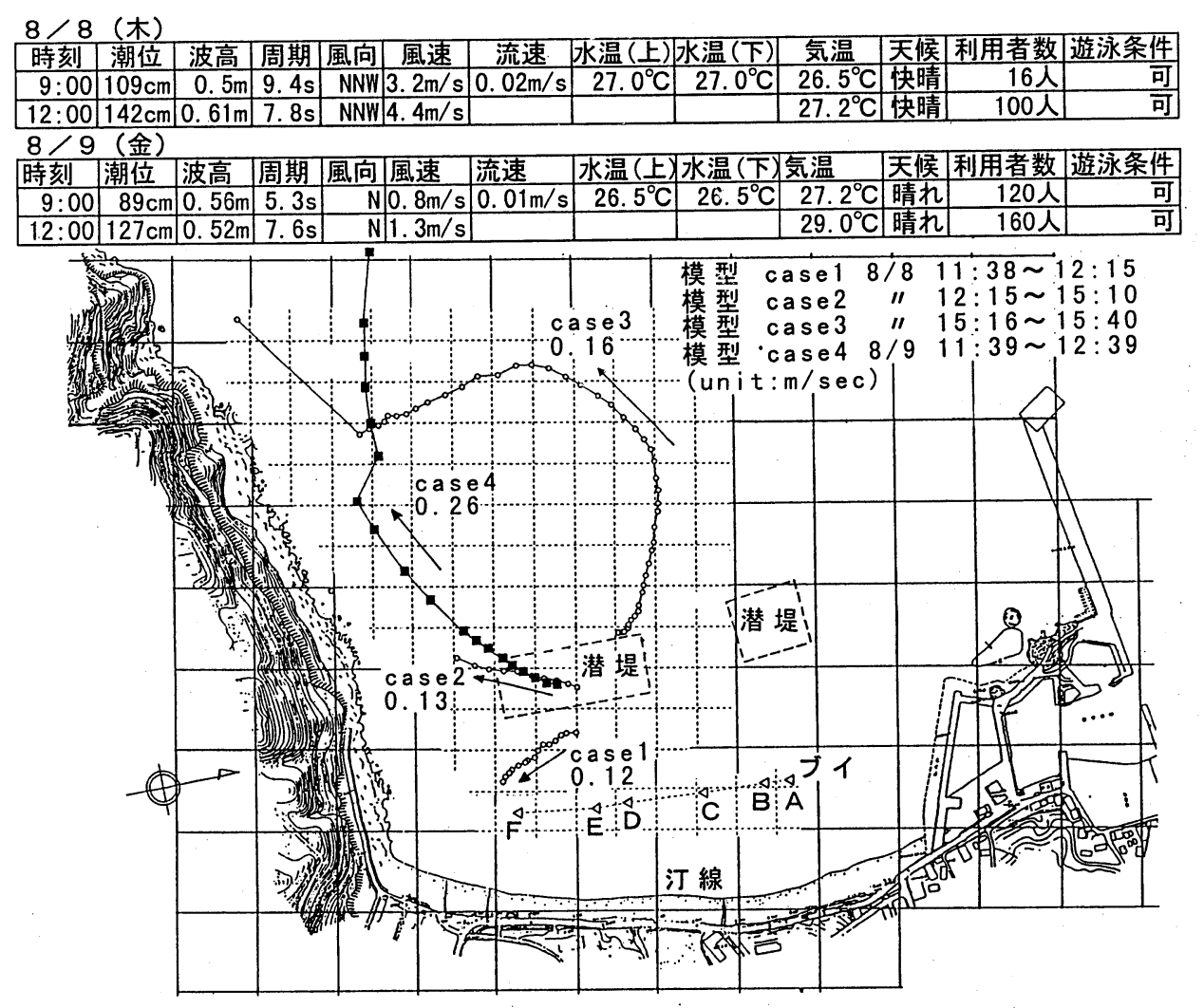

図一8 模型による流れ調査結果 (M海岸、平成 8 年 8 月 8 日ー 9 日)

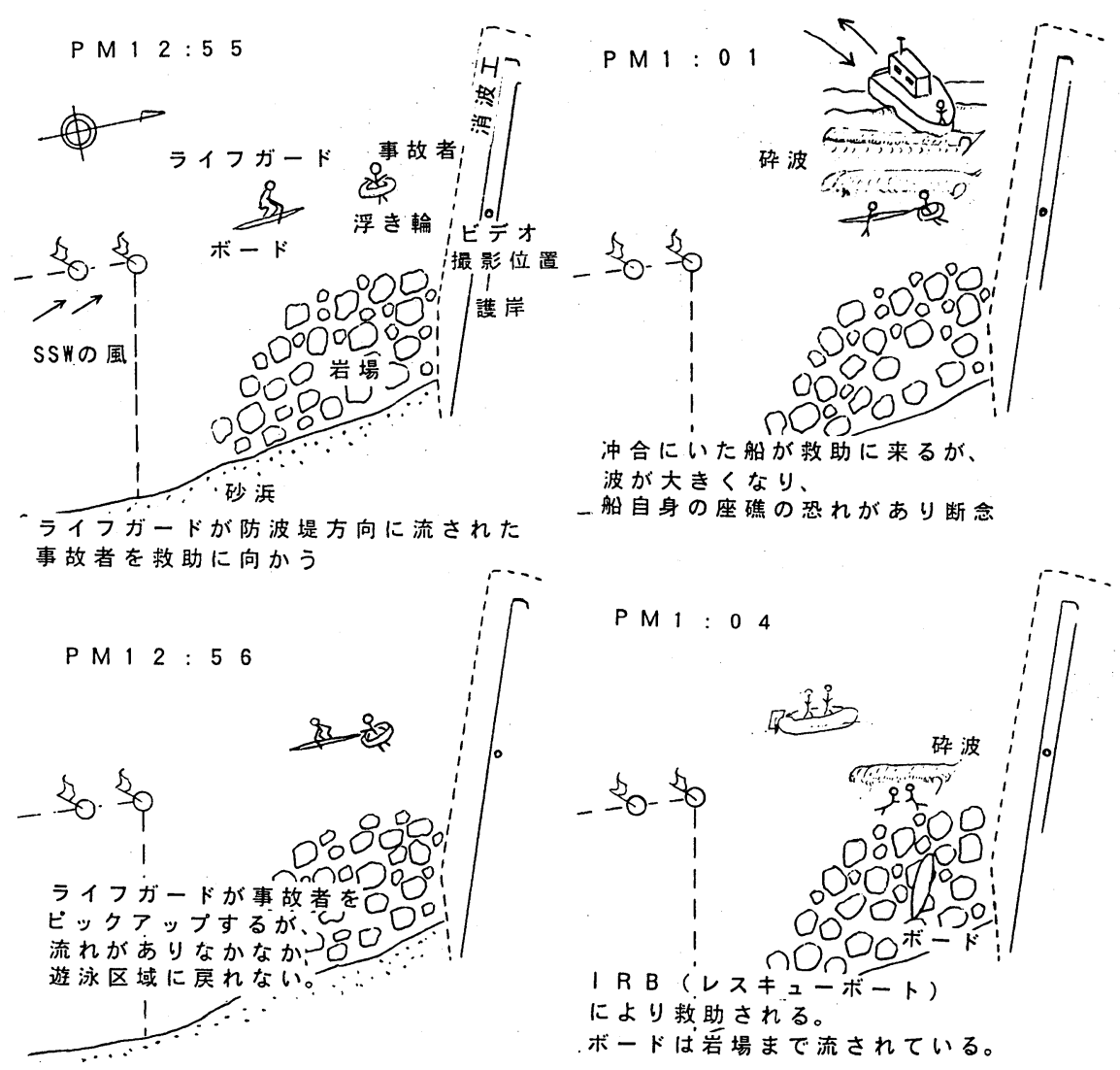

図 -9 事故の概要（神津島前浜、平成 8 年 8 月 3 日）

(3)模型による流れ調查

円筒模型は潜堤周辺から沖側の調査で用いており、図ー8は模型を流した結果の一例で、8月 8 日と 9 日のデ ータを示している。いずれも波高が $0.5 \sim 1 \mathrm{~m}$ で、風が NE、 $2 \sim 3 \mathrm{~m} / \mathrm{s}$ の場合である。 8 日のデータでは、潜 
堤から風の向きに流されている場合と潜堤開口部から沖合に流されている場合がある。9 日のデータでは、南側 の岩礁地帯に沿って流れており、沖合で $0.2 \mathrm{~m} / \mathrm{s}$ を越えるかなり速い流れとなっている。地元の漁師の方々から のヒヤリングではよく発生する流れであるとのことであった。

\section{(4) 事故の概要}

本調査中唯一の事故は 8 月 3 日に発生した。事故は図ー9に示すように海岸の北端で、遊泳区域のブイよりさ らに沖側で発生している。事故者は 20 歳男子で、浮き輪を使用していた。事故当時、たまたま図に示す護岸位 置にいたため、事故の様子をビデオにより撮影した。

事故当日は快晴で遊泳可であり、事故時は潮位 D. L. $+104 \mathrm{~cm}$ （ほぼ干潮）、波高 $0.6 \mathrm{~m}$ 、周期 $9.0 \mathrm{~s}$ 、風はSS $E$ で $1 \mathrm{~m} / \mathrm{s}$ であった。風速はさほど大きくないが、護岸位置から見た遊泳区域を示すブイの旗から推定すると海 面上の風速はもう少し大きそうである。事故時の様子を略記すると以下のようである。

1) 事故者が防波堤に向から流れによって突堤の根元の護岸付近まで流され、ライフガードがレスキューボー ドにて救助に向かい、到着する (12:56)。

2) 事故者が浮き輪を放さなかったことと、防波堤に向かう流れがあったためかなかなか遊泳区域に戻れない。

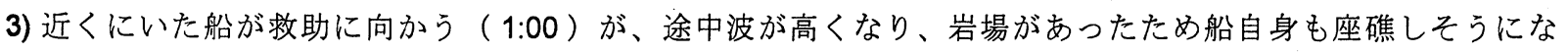
り救助することなく沖へ待避する。岩場の近くということもあり波は砕波してボア状になって進み、事故者とラ イフガードを岩場へ押し流すようになった。ライフガードはレスキューボードを放し、事故者と波の下へ潜り込 み、岩場へ押し流されるのを回避した。（放されたレスキューボードは一気に岩場へ流されている。）（1:02）

4) その後、波が少しおさまり、ライフガードのIRB（レスキューボート）により救助される。（1:04）

波高が比較的大きく、計測された風が小さかったため、防波堤に向かう流れが海浜流によるものか、風による 吹送流によるものか断定できないが、複合したものであると考えられる。ただし、当日は午前 11 時に浮き輪有 りと無しの 2 名のライフガードを同時に流して人流れ調查を実施しており、付近ではやはり北方向の風によって 浮き具なしの被験者が $0.07 \mathrm{~m} / \mathrm{s}$ で流れている。また、浮き具有りの被験者は、無しの場合より約 2 倍程度の速度 でそれよりやや沖側へ移動しており、やはり風の影響が大きいものと考えられる。この事故では、「流され戻れ ない危険」、「波で岩場に打ちつけられる危険」が具体的に把握できた。

\section{4。あとがき}

これまでの調査をふまえて、今後さらに研究を進めていく予定である。海水浴の安全性は、これまでのような 台風などの年に 1 度ぐらいの異常時を対象にしたものではなく、日常的な波や流れを対象としたものであり、こ れまでと異なった研究が必要となっている。また、砂浜だけでなく水の中の研究であり、波や流れに対する人の 応答の研究も含むなど、これまでの海岸工学の知見を基礎とするものの新たな組織的な研究が必要となっている。 こうした研究では、現地調查が重要であり、これまで以上にライフセーバーを含めた現地の関係者の方々との協 カが不可欠となっている。

現地調査にあたっては、東京都離島港湾部など多くの機関の方々のご協力を得ている。さらに、港湾技術研究 所の小島朗史水工部長のご指導を得るとともに、波浪の観測にあたっては永井紀彦海象観測研究室長掞よび協和 商工の方々のご協力を得ている。

\section{参考文献}

井上雅夫・島田広昭・光田佳也 (1988): 人工海浜によって造成された海水浴場における利用者意識、第 35 回海 岸工学講演会論文集、pp.762-766

宇多高明、小俣 篤・富田成秋、羽成英臣 (1991): マリンスポーツに適する自然条件に関する研究、第 38 回海 岸工学講演会論文集、pp.991-995

金沢 寛・平井宣典・太田耕栄・高橋重雄・鈴木高二朗・岡村知光・蓮見 隆・小林雅彦 (1996): 海水浴におけ

る安全性に関する一調查、土木学会第 51 回年次講演会講演概要集、第 2 部、pp.182-183.

小舟浩治 (1990): マリンスポーツに適する自然条件、平成 2 年度港研講演会講演集、pp.239-279

佐々木民雄・掘田新太郎・五十嵐 元・久保田 進 (1974): 海洋性レクリエーションに関する研究（第 2 報）

一九十九里海岸における海水浴の現地調査一、第 21 回海岸工学講演会論文集、pp.471-475.

塩見雅樹・戸引 勳・太田耕栄・高橋重雄・鈴木高二朗・岡村知光・蓮見 隆・小林雅彦 (1995): 海岸における 市民の安全性に関する一調查、海洋工学論文集、Vol. 11、pp.381-386.

高橋重雄・遠藤仁彦 (1994): 親水施設と市民の安全性に関する研究、平成 6 年度港湾技術研究所講演会講演集、 pp.119-138.

日本マリーナ・ビーチ協会編 (1992): ビーチ計画・設計マニュアル（運輸省港湾局監修）、118 p .

堀川清司・佐々木民雄・五十嵐 元 (1972): 海洋性レクリエーションとその環境、第 19 回海岸工学講演会論文 集、pp.83-91. 